\title{
A new species of Notodiaptomus Kiefer (Crustacea, Copepoda, Calanoida, Diaptomidae) from Brazil
}

\author{
Matsumura-Tundisi, T. ${ }^{\mathrm{a} *}$, Espindola, ELG. ${ }^{\mathrm{b}}$,Tundisi, JG. ${ }^{\mathrm{a}}$, Souza-Soares, F. ${ }^{\mathrm{a}}$ and Degani, RM. ${ }^{\mathrm{a}}$ \\ anstituto Internacional de Ecologia - IIE, Rua Bento Carlos, 750, CEP 13560-660, São Carlos, SP, Brazil

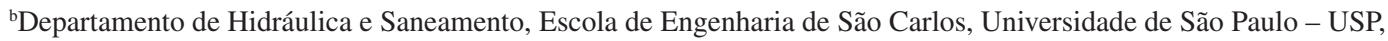 \\ Av. Trabalhador Sãocarlense, 400, CP 359, CEP 13566-590, São Carlos, SP, Brazil \\ *e-mail: takako@iie.com.br \\ Received January 8, 2010 - Accepted June 5, 2010 - Distributed October 31, 2010
}

(With 6 figures)

\begin{abstract}
Description of a new species of Diaptomidae (Crustacea, Copepoda, Calanoida) Notodiaptomus oliveirai is given from the material obtained at a reservoir at Barra Bonita, SP in 1992. The new species is very similar to Notodiaptomus henseni Dahl 1894 although both species can be found in the same locality, constituting two distinct populations. Notodiaptomus oliveirai seems to be endowed with great adaptability to changes in environmental conditions, extending its distribution to all the hydrographic basins in the state of São Paulo.
\end{abstract}

Keywords: new species, Brazil, Notodiaptomus oliveirai, geographical distribution, São Paulo State.

\section{Nova espécie de Notodiaptomus Kiefer (Crustacea Copepoda, Calanoida, Diaptomidae ) do Brasil}

\section{Resumo}

Descrição de espécie nova de Diaptomidae, Calanoida, Copepoda Notodiaptomus oliveirai é feita através do material proveniente da represa de Barra Bonita, SP, Brasil, onde foi encontrada pela primeira vez em 1992. A espécie nova apresenta grande semelhança com Notodiaptomus henseni Dahl 1894, porém ambas as espécies podem ser encontradas no mesmo ambiente constituindo duas populações diferentes. Notodiaptomus oliveirai, entretanto, parece possuir uma grande adaptabilidade a diversas condições ambientais, expandindo sua distribuição a todas as bacias hidrográficas do Estado de São Paulo.

Palavras-chave: espécie nova, Notodiaptomus oliveirai, distribuição geográfica, Estado de São Paulo.

\section{Introduction}

This material was collected during the expeditions carried out from 1992 to 1996 in the Project: "Comparative studies between Barra Bonita and Jurumirim reservoirs inserted respectively in the Tietê River and Paranapanema River basins on biogeophysical processes basis" coordinated by J.G. Tundisi and financed by FAPESP (Fundação de Amparo à Pesquisa do Estado de São Paulo) (Tundisi, 1994).

The drawings of the main pieces that characterise the species were made up by Espindola (1994) from Barra Bonita reservoir specimens, by camera lucida, and the pictures were taken from images captured in the microscope based on the specimens occurring in the same reservoir, but from samplings carried out in 2000 (BIOTA-FAPESP, 2003).

The type specimens are deposited in the collection of DCBU (Departamento de Ecologia e Biologia Evolutiva at the Universidade Federal de São Carlos, São Paulo, Brazil).

\section{Description of the New Species}

Notodiaptomus oliveirai spec. nov. (Figures 1-5)

Material examined-Holotype, $\widehat{\jmath}$, ( DCBU), Brazil, SP Barra Bonita, (22 31' 82' S and 48 31' 23" W), 2.x.2000, T. Matsumura-Tundisi coll.; Paratypes (DCBU): 27 ㅇ, $16 \hat{\jmath}$; same holotype.

Holotype, $\widehat{\sigma}$, body size: $1.15 \mathrm{~mm}$; general aspect of male as in Figure 1; right antenna of male as in Figure $3 \mathrm{a}, 3 \mathrm{~b} ; 5^{\text {th }}$ leg of male presents the terminal claw relatively short almost the same length as the second segment of exopodite and the proximal margin of second segment of exopodite is half the distal margin with a strong concavity in the inner margin (Figure 5a, 5b).

Paratypes,, , $1.29 \mathrm{~mm}$ of length; general aspect of female as in Figure $4 a, 4 b$; right $5^{\text {th }}$ leg of female as in Figure $5 \mathrm{a}, 5 \mathrm{~b}$ where it can be seen that the endopodite corresponds to half the size of the first exopodite.

Notodiaptomus oliveirai spec. nov. is very similar to Notodiaptomus henseni (Dahl, 1894). Both 

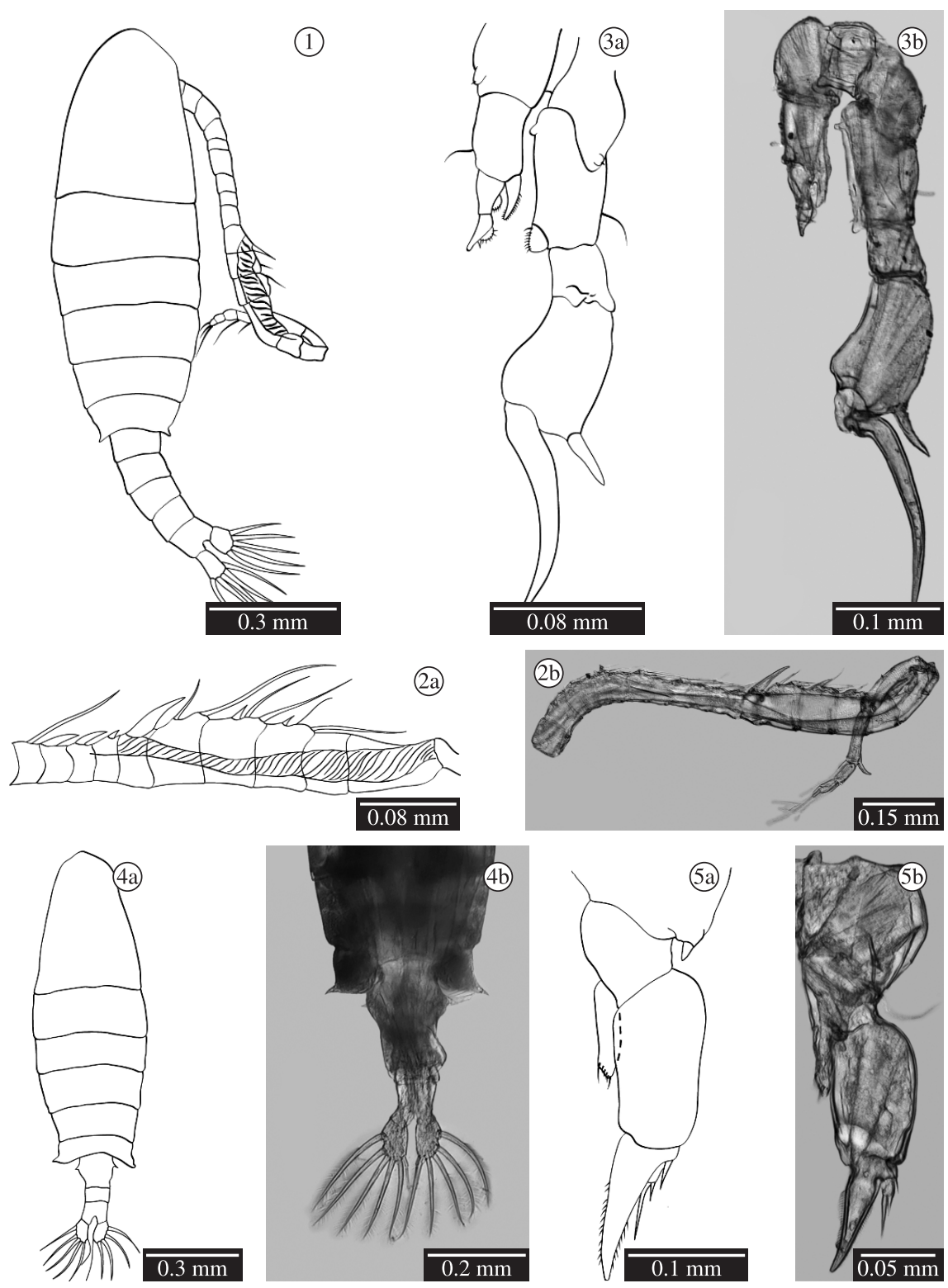

Figures 1-5. Notodiaptomus oliveirai spec. nov.: 1) general aspect ( male); 2) $5^{\text {th }}$ leg (male, drawing and picture); 3) right antennae (male, drawing and picture); 4) female (general aspect, drawing and part of thorax and abdomen, picture); and 5) $5^{\text {th }} \operatorname{leg}$ (female, drawing and picture).

species present a knob at the proximal inner corner of basipodite II, but the shape of the second segment of exopodite is different, without inner margin concavity present in this new species (see figures in Kiefer, 1936).

Etymology - The species name was given in honour of Abilio Lopes de Oliveira- Neto (in memoriam).

\section{Geographical Distribution of Notodiaptumus oliveirai spec. nov. in São Paulo State, Brazil, and its Ecology (Figure 6)}

The new species was recorded for the first time in Barra Bonita Reservoir, São Paulo State, Brazil, in 1992, together with other Calanoida populations (Espindola, 1994, Matsumura-Tundisi and Tundisi, 2003).

Notodiaptomus oliveirai spec. nov. is probably a species adapted to the eutrophic conditions of reservoirs as have been observed in Barra Bonita reservoir. It was registered in this locality in 1992, July, at first in small number, but in 1993, became more abundant and in 2002, it was the most abundant species, outnumbering Notodiaptomus iheringi dominant in the Calanoida population of Barra Bonita reservoir (Tundisi et al., 2008).

In recent studies carried out in 350 water bodies (reservoirs, lakes and ponds) in São Paulo state (BIOTA/ FAPESP, 2003), Notodiaptomus oliveirai spec. nov. was 


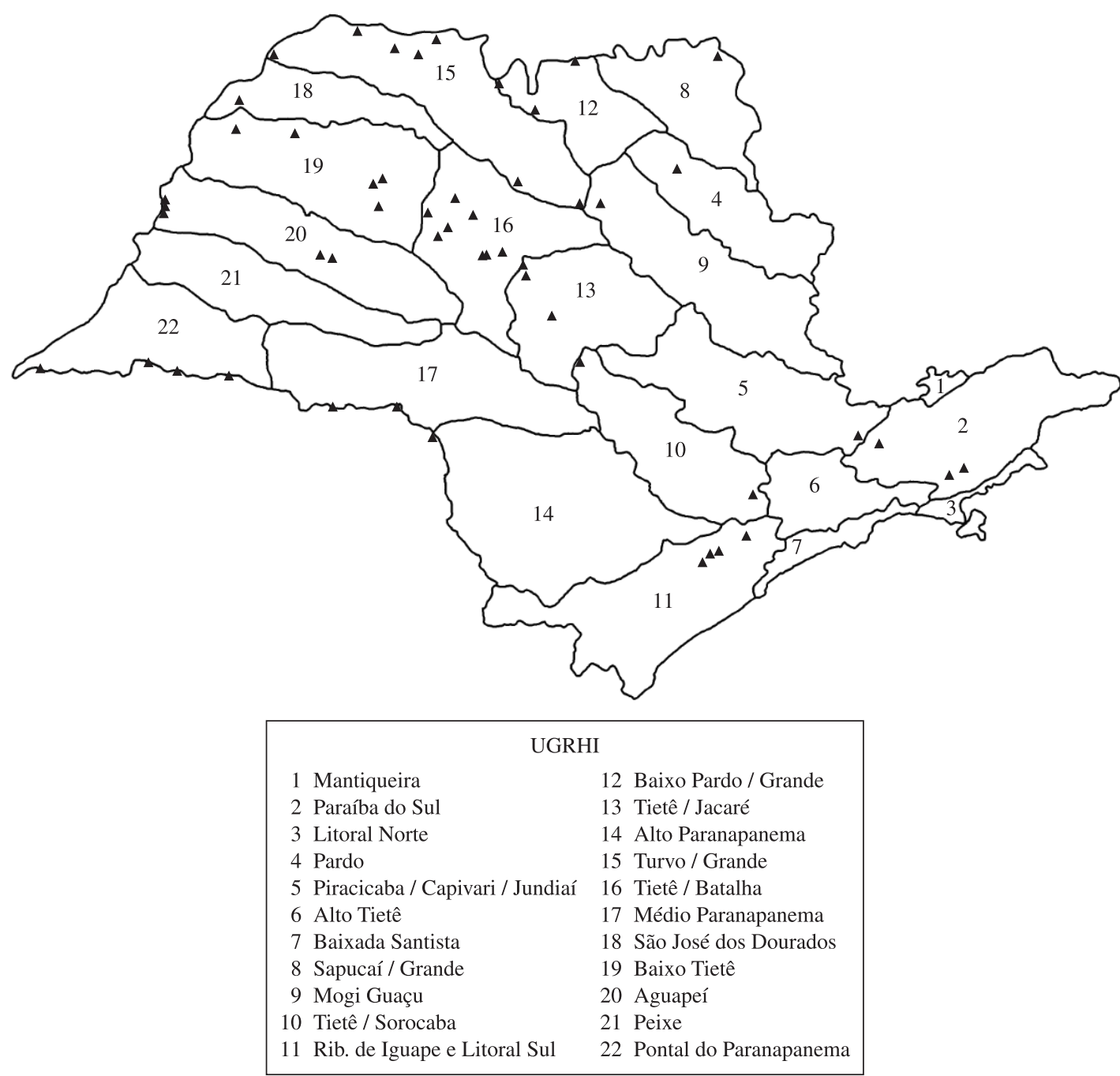

Figure 6. Geographical distribution of Notodiaptomus oliveirai spec. nov. at the 22 UGRHI of São Paulo State.

found in several reservoirs of Paranapanema basin (Rosana, Taquaruçu, Salto Grande, Rosana, Canoa Grande, Tavares, Jurumirim, Capivara, Chavantes reservoirs); Tietê/Jacaré basin (Bariri, Ibitinga, Barra Bonita reservoirs); Sapucai/ Grande basin (Jaguara, Igarapava reservoirs); Piracicaba/ Jundiaí/Capivara basin (Paramirim, Igarata, Cachoeira reservoirs, Lagoa Pousada); Tietê/Sorocaba basin (Prainha reservoir); Paraíba do Sul basin (Paraibuna reservoir); Ribeira do Iguape basin (Porto Raso, Serraria, Alecrim, Cachoeira da França, Barra reservoirs); Tietê/Batalha basin (Ibitinga, Promissão reservoirs, Tietê Rivers); Baixo Pardo/ Grande basin (Porto Colombia, Marimbondo reservoirs); Turvo/Grande basin (Agua Vermelha reservoir and Rio Grande river); São José dos Dourados basin ( Ilha Solteira reservoir, São José dos Dourados river); Lower Tietê River basin ( Nova Avanhandava, Três Irmãos reservoirs); Aguapeí basin (Paraná River, in some ponds). Figure 6 shows the geographical distribution of Notodiaptomus oliveirai in 22 UGRHIs (Unidade de Gerenciamento de
Recursos Hídricos, in São Paulo state) showing that the species was present in most of the watersheds of São Paulo state, except the Alto Tietê river, Mantiqueira, Mogi Guaçu river, Pardo river and Paraná river basin (UGRHI São José dos Dourados).

The new species seems to have a great plasticity in relation to environmental conditions, and it has wide distribution, probably due to the ability of rapid dispersion mechanisms. It is found in great number in the main watersheds of São Paulo State after the first record that occurred in 1992, in the Barra Bonita Reservoir.

Acknowledgements - This work is part of the BIOTA/FAPESP The Biodiversity Virtual Institute Program (www.biotasp.org.br). The authors express thanks to FAPESP (Fundação de Amparo à Pesquisa do Estado de São Paulo - Process nº 98/5091-2 ), to CNPq (Conselho Nacional de Desenvolvimento Científico e Tecnológico - Process no 301602/2005-0) and to PenteadoDias, A.M. for help with the procedures for the new species description and deposition at the DCBU collection museum of UFSCar. 


\section{References}

BIOTA/FAPESP, 2003. Biodiversity of freshwater zooplankton of São Paulo State, Brazil. In: Proceeding Report.

ESPINDOLA, ELG., 1994. Dynamic of congeneric species of Notodiaptomus (Copepoda Calanoida) from Barra Bonita Reservoir, São Paulo. University of São Paulo, 363 p. [Phd thesis].

KIEFER, F., 1936. Über die Systematik der südamerikanis Diaptomiden (Crustacea Copepoda). Zoologischer Anzeiger, vol. 15 , no. 11, p. 194-200.

MATSUMURA-TUNDISI, T. and TUNDISI, JG., 2003. Calanoida ( Copepoda) species composition changes in the reservoirs of
São Paulo State (Brazil) in the last twenty years. Hydrobiologia, vol. 504, p. 215-222.

TUNDISI, JG., 1994. Report. “Comparative studies between Barra Bonita and Jurumirim reservoirs ( structure and functioning) inserted respectively in Tietê River and Paranapanema River basins on biogeophysical processes basis". Process: 91/0612-5. vol. I-II.

TUNDISI, JG., MATSUMURA-TUNDISI, T. and ABE, DS., 2008. The ecological dynamics of Barra Bonita (Tietê River, SP, Brazil) reservoir: implications for its biodiversity. Brazilian Journal of Biology, vol. 68, suppl. 4, p. 1079-1098. 